\title{
THE EFFECT OF POLYPROPYLENE THICKNESS AND TEMPERATURE ON THE QUALITY OF CAYENNE PEPPER DURING STORAGE
}

\author{
Tri Luchi Proklamita ${ }^{*}{ }^{凶}$, Aloysius Ng. Lende ${ }^{2}$ \\ *1, 2 Department Food Crops and Horticulture, State Agricultural Polytechnic of Kupang, Indonesia
}

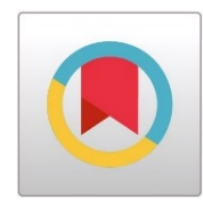

DOI: https://doi.org/10.29121/granthaalayah.v8.i10.2020.1901

Article Type: Research Article

Article Citation: Tri Luchi

Proklamita, and Aloysius Ng. Lende. (2020). THE EFFECT OF

POLYPROPYLENE THICKNESS AND

TEMPERATURE ON THE QUALITY

OF CAYENNE PEPPER DURING

STORAGE. International Journal of

Research -GRANTHAALAYAH,

8(10), 278-284.

https://doi.org/10.29121/granthaa

layah.v8.i10.2020.1901

Received Date: 05 October 2020

Accepted Date: 31 October 2020

Keywords:

Polypropylene

Temperature

Cayenne Pepper

Storage Time

\section{ABSTRACT}

This study aims to determine the effect of different combinations of plastic thickness and temperature treatment combinations on the quality of cayenne pepper during storage, to determine the combination of plastic thickness and the right temperature to maintain the quality of cayenne pepper during storage. This study used a completely randomized design (CRD) with 9 treatments. The treatments tried in this study were thickness and temperature, namely Polypropylene $0.3 \mathrm{~mm}+$ tissue at $5^{\circ} \mathrm{C}$, Polypropylene $0.3 \mathrm{~mm}+$ tissue at $10^{\circ} \mathrm{C}$, Polypropylene $0.3 \mathrm{~mm}+$ tissue at $15^{\circ} \mathrm{C}$, Polypropylene $0.4 \mathrm{~mm}+$ tissue at $5^{\circ} \mathrm{C}$, Polypropylene $0.4 \mathrm{~mm}+$ tissue at $10^{\circ} \mathrm{C}$, Polypropylene $0.4 \mathrm{~mm}+$ tissue at $15^{\circ} \mathrm{C}$, Polypropylene $0.5 \mathrm{~mm}+$ tissue at $5^{\circ} \mathrm{C}$, Polypropylene $0.5 \mathrm{~mm}+$ tissue at $10^{\circ} \mathrm{C}$, Polypropylene $0.5 \mathrm{~mm}$ + tissue at $15^{\circ} \mathrm{C}$. The treatment was repeated 3 times so that there were 27 experimental units. The results that showed the combination treatment of packaging thickness and temperature had a very significant effect on the storage quality of cayenne pepper on weight loss, vitamin C, texture, moisture content, and color, but had no significant effect on the color of the 8th day of the watershed. The combination treatment of plastic packaging thickness of $0.5 \mathrm{~mm}$ and temperature of $5^{\circ} \mathrm{C}$ can give the best effect on texture, vitamin $\mathrm{C}$, moisture content, weight loss, and color, but at a thickness of $0.3 \mathrm{~mm}$ plastic and a temperature of $15^{\circ} \mathrm{C}$ does not give the best results on color 8th day.

\section{INTRODUCTION}

Cayenne pepper is a vegetable commodity that people cannot leave behind in their daily lives. In addition to vegetables and as a food flavoring, bird's eye chilies have other uses. Cayenne pepper is considered important as an ingredient in the food, beverage, and pharmaceutical industries due to its spicy taste (Setiadi, 2001).

The spicy taste of cayenne pepper is caused by the content of capsaicin and dihydrocapsaicin. The homo content of capsaicin and homodihidro capsaicin is found in very small concentrations (Santika, 2007). Capsaicin levels will decrease along with the deterioration process that leads to aging. Langi (2000) states that capsaicin in chilies will actually be produced 20 days after flowering. This production will continue to increase and reach a maximum of 3040 days after flowering, after which the capsaicin in chilies decreases. This is in accordance with the conditions that occurred during the main harvest, the price of cayenne pepper greatly decreased because the amount of harvest was very large. This causes losses for farmers who are forced to sell their crops at low prices so that their planting capital

(C) 2020 The Author(s). This is an open access article distributed under the terms of the Creative Commons Attribution License, which permits unrestricted use, distribution, and reproduction in any medium, provided the original author and source are credited. 
Tri Luchi Proklamita, and Aloysius Ng. Lende

does not return. Therefore, it is necessary to have an experiment on postharvest handling of the quality of cayenne pepper.

\section{Material and Method}

The tools used in this research were analytical scales, cuvettes, desiccators, refrigerators, Erlenmeyer, knives, sliced boards, Petri dishes, spatulas, filter paper, laser thermometers, screw micrometers, ohause scales, scissors, trays, cameras, markers, rulers, burette, texture analyzer, oven, measuring flask, dropper pipette, measuring cup, sealer, funnel, cardboard, writing instruments, and camera.

The materials used are cayenne pepper with varieties of Kresna, polypropylene plastic, iodine, $70 \%$ alcohol, distilled water, tissue, and label paper.

This study used a completely randomized design (CRD) with 9 treatments. The treatments tried in this study were thickness and temperature, namely Polypropylene $0.3 \mathrm{~mm}+$ tissue at $5^{\circ}$, Polypropylene $0.3 \mathrm{~mm}+$ tissue at $10^{\circ} \mathrm{C}$, Polypropylene $0.3 \mathrm{~mm}+$ tissue at $15^{\circ} \mathrm{C}$, Polypropylene $0.4 \mathrm{~mm}+$ tissue at $5^{\circ} \mathrm{C}$, Polypropylene $0.4 \mathrm{~mm}+$ tissue at $10^{\circ} \mathrm{C}$, Polypropylene $0.4 \mathrm{~mm}+$ tissue at $15^{\circ} \mathrm{C}$, Polypropylene $0.5 \mathrm{~mm}+$ tissue at $5^{\circ} \mathrm{C}$, Polypropylene $0.5 \mathrm{~mm}+$ tissue at $10^{\circ} \mathrm{C}$, Polypropylene $0.5 \mathrm{~mm}+$ tissue at $15^{\circ} \mathrm{C}$. The treatment was repeated 3 times so that there were 27 experimental units. The tissue used was 2 pieces of facial tissue each weighing $0.79 \mathrm{~g}$.

\section{RESULTS AND DISCUSSION}

\section{Preliminary Observations}

The average laboratory analysis results of vitamin $\mathrm{C}$, moisture content, weight loss, texture and color of cayenne pepper before treatment can be seen in Table 1.

Table 1: Average Initial Analysis of Vitamin C, Water Content, Weight Loss, Texture and Color of Cayenne Pepper.

\begin{tabular}{|l|l|}
\hline Observation variable & Value of initial analysis \\
\hline Vitamin C (mg) & 121 \\
\hline Moisture content (\%) & 65,12 \\
\hline Weight(g) & 60 \\
\hline Texture (g) & 1489 \\
\hline Color & 1,1 \\
\hline
\end{tabular}

Source: Results of Agricultural Product Technology Laboratory Analysis, State Agricultural Polytechnic of Kupang Indonesia, 2018.

Based on the results of the initial analysis in Table 1 values of texture, weight loss, moisture content, vitamin C, and color were carried out to determine the initial content of cayenne pepper before giving treatment to cayenne pepper, so that it can compare with the final value after storage and know the presentation of the effect of using several thicknesses of polypropylene plastic and temperature. different from the quality of cayenne pepper to changes in texture, weight loss, moisture content, vitamin $\mathrm{C}$, and color of cayenne pepper after being treated.

\section{Vitamin C Cayenne Pepper (mg)}

Treatment at $5^{\circ} \mathrm{C}$ at $8 \mathrm{DAS}$ storage gave the highest value of vitamin $\mathrm{C}$ in chilies but was significantly different from all treatments. Observation of 16 DAS showed the highest vitamin C value (77.1) and was significantly different from all treatments. The average height of vitamin $C$ in the plastic treatment of $0.5 \mathrm{~mm}$ and a temperature of $5^{\circ} \mathrm{C}$, can prevent evaporation at high water and air permeability so that it will inhibit the respiration process and enzyme activity as well as metabolic processes. The thickness of the polypropylene plastic packaging which has a thickness of $0.5 \mathrm{~mm}$ can retain the vitamin $\mathrm{C}$ content because polypropylene plastic has good resistance to moisture penetration (Rochman, 2007). This is also supported by Andarwulan and Koswara (1992) who stated that the stability of vitamin $\mathrm{C}$ usually increases with a decrease in storage temperature. 
Table 2: Average Vitamin $C$ due to the effect of plastic packaging thickness and temperature on the quality of cayenne pepper during storage 8 and 16 watersheds.

\begin{tabular}{|c|c|c|}
\hline \multirow{2}{*}{ Treatment } & \multicolumn{2}{|c|}{ Vitamin C } \\
\cline { 2 - 3 } & $8 \mathrm{DAS}$ & $16 \mathrm{DAS}$ \\
\hline Polypropylene 0,3 $\mathrm{mm}+$ suhu $5^{\circ} \mathrm{C}$ & $99,6 \mathrm{f}$ & $70,9 \mathrm{~g}$ \\
\hline Polypropylene $0,3 \mathrm{~mm}+$ suhu $10^{\circ} \mathrm{C}$ & $95,9 \mathrm{e}$ & $63,9 \mathrm{c}$ \\
\hline Polypropylene $0,3 \mathrm{~mm}+$ suhu $15^{\circ} \mathrm{C}$ & $79,7 \mathrm{a}$ & $56,0 \mathrm{a}$ \\
\hline Polypropylene $0,4 \mathrm{~mm}+$ suhu $5^{\circ} \mathrm{C}$ & $104,2 \mathrm{~h}$ & $72,3 \mathrm{~h}$ \\
\hline Polypropylene $0,4 \mathrm{~mm}+$ suhu $10^{\circ} \mathrm{C}$ & $87,9 \mathrm{c}$ & $66,3 \mathrm{~d}$ \\
\hline Polypropylene $0,4 \mathrm{~mm}+$ suhu $15^{\circ} \mathrm{C}$ & $84,4 \mathrm{~b}$ & $58,7 \mathrm{~b}$ \\
\hline Polypropylene $0,5 \mathrm{~mm}+$ suhu $5^{\circ} \mathrm{C}$ & $108,1 \mathrm{i}$ & $77,1 \mathrm{i}$ \\
\hline Polypropylene $0,5 \mathrm{~mm}+$ suhu $10^{\circ} \mathrm{C}$ & $100,7 \mathrm{~g}$ & $70,4 \mathrm{f}$ \\
\hline Polypropylene 0,5 $\mathrm{mm}+$ suhu $15^{\circ} \mathrm{C}$ & $88,9 \mathrm{~d}$ & $69,2 \mathrm{e}$ \\
\hline & 0,8 & 0,4 \\
\hline
\end{tabular}

Note: The numbers followed by the same letter in the same column are not significantly different in the HSD 5 test \%, DAS: (Honestly Significance Diffirence, Days After Saving)

The decrease in vitamin $\mathrm{C}$ content was due to the lower plastic thickness treatment of $0.5 \mathrm{~mm}$ and a high temperature of $15^{\circ} \mathrm{C}$ so that it could not withstand the evaporation that occurred in the chilies which resulted in an increase in the enzyme due to an increase in temperature of $15^{\circ} \mathrm{C}$. This under the statements of Harper (1986) and Wirnano (1988) which states that during storage, vitamin C levels tend to decrease. High storage temperature and low plastic thickness will affect the decrease in vitamin $C$ levels. The oxidation process will be hampered when vitamin $C$ is in a very acidic state or high temperature because the content of vitamin $C$ can dissolve in water during the respiration process. This is also supported by Noor (1992) who states that the intensity of the enzyme effect depends on the amount contained in the material, the effect of the thickness of the packaging used, and the working conditions of the enzyme. Vitamin $\mathrm{C}$ is a vitamin that is very easily damaged compared to other types of vitamins. Changes in vitamin $\mathrm{C}$ are influenced by changes in fruit moisture content and room temperature during storage. Vitamin $C$ is very soluble in water, easily oxidized and the process is accelerated by heat, light or oxidizing enzymes and by the catalyst and iron. Oxidation will be inhibited if vitamin $\mathrm{C}$ is left in a low temperature. Fruit that is still easy (raw) contains more vitamin C the older the fruit, the less vitamin C (Prawirokusumo, 1994).

\section{Water Content (\%)}

Thickness treatment of Polypropylene packaging showed a very significant effect on the water content of cayenne pepper on the 8th day and on the 16th day after storage.

Table 3: Average Water Content Due to the Effect of Plastic Packaging Thickness and Temperature on Quality of Cayenne Pepper during Storage 8 and 16 DAS.

\begin{tabular}{|c|c|c|}
\hline \multirow{2}{*}{ Treatment } & \multicolumn{2}{|c|}{ Water content } \\
\cline { 2 - 3 } & $8 \mathrm{DAS}$ & $16 \mathrm{DAS}$ \\
\hline Polypropylene 0,3 mm + suhu $5^{\circ} \mathrm{C}$ & $71,6 \mathrm{f}$ & $87,3 \mathrm{e}$ \\
\hline Polypropylene $0,3 \mathrm{~mm}+$ suhu $10^{\circ} \mathrm{C}$ & $68,1 \mathrm{c}$ & $73,8 \mathrm{~b}$ \\
\hline Polypropylene $0,3 \mathrm{~mm}+$ suhu $15^{\circ} \mathrm{C}$ & $66,0 \mathrm{a}$ & $72,4 \mathrm{a}$ \\
\hline Polypropylene $0,4 \mathrm{~mm}+$ suhu $5^{\circ} \mathrm{C}$ & $74,5 \mathrm{~h}$ & $85,2 \mathrm{~d}$ \\
\hline Polypropylene $0,4 \mathrm{~mm}+\mathrm{suhu} 10^{\circ} \mathrm{C}$ & $69,4 \mathrm{e}$ & $80,2 \mathrm{c}$ \\
\hline Polypropylene $0,4 \mathrm{~mm}+\mathrm{suhu} 15^{\circ} \mathrm{C}$ & $67,0 \mathrm{~b}$ & $73,5 \mathrm{~b}$ \\
\hline Polypropylene $0,5 \mathrm{~mm}+$ suhu $5^{\circ} \mathrm{C}$ & $78,5 \mathrm{i}$ & $96,2 \mathrm{f}$ \\
\hline Polypropylene $0,5 \mathrm{~mm}+$ suhu $10^{\circ} \mathrm{C}$ & $72,3 \mathrm{~g}$ & $80,0 \mathrm{c}$ \\
\hline Polypropylene $0,5 \mathrm{~mm}+$ suhu $15^{\circ} \mathrm{C}$ & $68,9 \mathrm{~d}$ & $73,2 \mathrm{ab}$ \\
\hline HSD value $5 \%$ & 0,3 & 1,0 \\
\hline
\end{tabular}

Note: The numbers followed by the same letter in the same column are not significantly different in the HSD 5 test \%, DAS: (Honestly Significance Diffirence, Days After Saving). 
Treatment of $0.5 \mathrm{~mm}$ Polypropylene + temperature $15{ }^{\circ} \mathrm{C}$ has a packaging thickness and low temperature can inhibit the transpiration and respiration process of cayenne pepper. High temperatures with low thickness and low humidity can accelerate the process of product respiration and cause faster loss of water content and decrease in vitamin C content (Utama et al., 2002).

In the Polypropylene treatment of $0.3 \mathrm{~mm}+$ temperature of $15^{\circ} \mathrm{C}$, it has larger pores and high temperature compared to a thickness of $0.5 \mathrm{~mm}$ so that it cannot inhibit the respiration process of cayenne pepper. This is supported by Buckle et al (1987) who stated that the permeability of plastics is influenced by temperature, packaging thickness, composition, atmospheric conditions (such as RH, for water vapor removal). Thin plastic which is flexible has different properties in its permeability to gases, such as nitrogen, oxygen, and water vapor.

\section{The texture of cayenne pepper (g)}

The average height of the texture in the Polypropylene treatment of $0.5 \mathrm{~mm}+$ temperature of $5^{\circ} \mathrm{C}$ has a thicker packaging thickness and a low temperature so that it will inhibit the respiration process which can soften the fruit in cayenne pepper. This is supported by Meyer (1973) who stated that the factor that affects softness is pectin which is present in the form of protopectin. Furthermore, the fruit that undergoes a ripening process, protopectin is converted into pectin by the polygalacturonase enzyme so that the fruit becomes soft. The effect of differences in the thickness of plastic packaging can affect the softness of the fruit. This is also supported by Wills et al., (1981) and Brown (1992) who state that the thickness of the polypropylene plastic packaging used to package horticultural products can inhibit and reduce the process of respiration and transpiration that occurs in the product which allows an increase in product freshness horticulture.

Table 4: Average Texture Due to the Effect of Plastic Packaging Thickness and Temperature on Quality of Cayenne Pepper during Storage 8 and 16 DAS.

\begin{tabular}{|c|c|c|}
\hline Treatment & \multicolumn{2}{|c|}{ Texture } \\
\hline & $8 \mathrm{DAS}$ & $16 \mathrm{DAS}$ \\
\hline Polypropylene $0,3 \mathrm{~mm}+$ suhu $5^{\circ} \mathrm{C}$ & $1204,7 \mathrm{~g}$ & $1098,3 \mathrm{~g}$ \\
\hline Polypropylene $0,3 \mathrm{~mm}+$ suhu $10^{\circ} \mathrm{C}$ & $857,7 \mathrm{c}$ & $805,0 \mathrm{~d}$ \\
\hline Polypropylene $0,3 \mathrm{~mm}+$ suhu $15^{\circ} \mathrm{C}$ & $759,0 \mathrm{a}$ & $624,0 \mathrm{a}$ \\
\hline Polypropylene $0,4 \mathrm{~mm}+\operatorname{suhu} 5^{\circ} \mathrm{C}$ & $1261,5 \mathrm{~h}$ & $1107,5 \mathrm{~g}$ \\
\hline Polypropylene $0,4 \mathrm{~mm}+\mathrm{suhu} 10^{\circ} \mathrm{C}$ & $951,8 \mathrm{e}$ & $851,8 \mathrm{e}$ \\
\hline Polypropylene $0,4 \mathrm{~mm}+\mathrm{suhu} 15^{\circ} \mathrm{C}$ & $810,3 \mathrm{~b}$ & $756,7 \mathrm{c}$ \\
\hline Polypropylene $0,5 \mathrm{~mm}+\mathrm{suhu} 5^{\circ} \mathrm{C}$ & $1372,3 \mathrm{i}$ & $1117,0 \mathrm{~g}$ \\
\hline Polypropylene $0,5 \mathrm{~mm}+\operatorname{suhu} 10^{\circ} \mathrm{C}$ & $1030,7 \mathrm{f}$ & $959,0 \mathrm{f}$ \\
\hline Polypropylene $0,5 \mathrm{~mm}+$ suhu $15^{\circ} \mathrm{C}$ & $876,8 \mathrm{~d}$ & $679,5 \mathrm{~b}$ \\
\hline HSD value $5 \%$ & 14,4 & 24,0 \\
\hline
\end{tabular}

Note: The numbers followed by the same letter in the same column are not significantly different in the HSD 5 test \%, DAS: (Honestly Significance Diffirence, Days After Saving).

Treatment Polypropylene $0.3 \mathrm{~mm}+$ temperature $15^{\circ} \mathrm{C}$ had the lowest cayenne pepper texture on the 8th day (759.0) and 16th day (624.0) which were very significantly different from all treatments. The type of packaging thickness of $0.3 \mathrm{~mm}$ at a temperature of $15^{\circ} \mathrm{C}$ has a lower cayenne pepper texture compared to treatment $\mathrm{P} 7$ with a packaging thickness of $0.5 \mathrm{~mm}$ at $5^{\circ} \mathrm{C}$. Treatment Polypropylene $0.3 \mathrm{~mm}+$ temperature $15^{\circ} \mathrm{C}$ has a lower plastic thickness of $0.3 \mathrm{~mm}$ so that the process occurs respiration and transpiration in cayenne pepper and cayenne pepper become softer. This decrease in hardness value occurs due to the degradation of water-insoluble pectin (protopectin) and turns into water-soluble pectin. This results in decreased cell wall cohesion that binds one cell wall to another. The longer the storage and the thinner the Polypropylene packaging used can cause the texture to decrease, this is due to the accumulation of heat so that the respiration rate increases and stimulates the ripening of cayenne pepper so that the longer the cayenne pepper texture is stored, the soft it will be (Kismaryanti, 2007). 
The Effect of Polypropylene Thickness and Temperature on The Quality of Cayenne Pepper During Storage

\section{Shrinkage Weight (g)}

Polypropylene treatment showed a significant effect on shrinkage weight of cayenne pepper on the 8th day and had a very significant effect on the 16 th day after storage.

Table 5: Average Shrinkage Weight Effect of Plastic Packaging Thickness and Temperature on Quality of Cayenne Pepper during Storage.

\begin{tabular}{|c|c|c|}
\hline \multirow{2}{*}{ Treatment } & \multicolumn{2}{|c|}{ Shrinkage Weight (g) } \\
\cline { 2 - 3 } & $8 \mathrm{DAS}$ & $16 \mathrm{DAS}$ \\
\hline Polypropylene $0,3 \mathrm{~mm}+$ suhu $5^{\circ} \mathrm{C}$ & $9,4 \mathrm{~b}$ & $10,3 \mathrm{~b}$ \\
\hline Polypropylene $0,3 \mathrm{~mm}+$ suhu $10^{\circ} \mathrm{C}$ & $10,7 \mathrm{e}$ & $12,0 \mathrm{c}$ \\
\hline Polypropylene $0,3 \mathrm{~mm}+$ suhu $15^{\circ} \mathrm{C}$ & $12,5 \mathrm{f}$ & $12,7 \mathrm{c}$ \\
\hline Polypropylene $0,4 \mathrm{~mm}+$ suhu $5^{\circ} \mathrm{C}$ & $9,7 \mathrm{c}$ & $9,9 \mathrm{~b}$ \\
\hline Polypropylene $0,4 \mathrm{~mm}+$ suhu $10^{\circ} \mathrm{C}$ & $9,9 \mathrm{c}$ & $10,4 \mathrm{~b}$ \\
\hline Polypropylene $\mathrm{PP} 0,4 \mathrm{~mm}+$ suhu $15^{\circ} \mathrm{C}$ & $10,9 \mathrm{e}$ & $11,0 \mathrm{bc}$ \\
\hline Polypropylene $0,5 \mathrm{~mm}+\operatorname{suhu} 5^{\circ} \mathrm{C}$ & $7,3 \mathrm{a}$ & $8,3 \mathrm{a}$ \\
\hline Polypropylene $0,5 \mathrm{~mm}+$ suhu $10^{\circ} \mathrm{C}$ & $9,3 \mathrm{~b}$ & $9,8 \mathrm{~b}$ \\
\hline Polypropylene $0,5 \mathrm{~mm}+$ suhu $15^{\circ} \mathrm{C}$ & $10,3 \mathrm{~d}$ & $10,8 \mathrm{bc}$ \\
\hline HSD value $5 \%$ & 0,2 & 1,3 \\
\hline
\end{tabular}

Note: The numbers followed by the same letter in the same column are not significantly different in the HSD 5 test \%, DAS: (Honestly Significance Diffirence, Days After Saving).

The average height of weight loss in the Polypropylene treatment is $0.3 \mathrm{~mm}+$ a temperature of $15^{\circ} \mathrm{C}$ shows that the Polypropylene $0,3 \mathrm{~mm}+$ suhu $15^{\circ} \mathrm{C}$ treatment has the lowest packaging thickness at high temperatures so that the transpiration and respiration processes can run smoothly. This is supported by Iflah et al., (2012) which states that weight loss during storage is one of the quality parameters that reflects the level of freshness of horticultural products. The weight reduction is influenced by the thickness of the plastic against the water vapor permeability, where during storage, apart from respiration, transpiration also occurs, namely the evaporation of water from the surface of the fruit which causes dryness and wilting. This is also supported by Qantyah (2004) who states that weight loss is caused by the process of respiration and respiration in the fruit. Weight loss is also due to the loss of water from cayenne pepper. The high-water loss will cause withering and wrinkling of the fruit. According to Lathifa research (2013) which states that the event of evaporation causes the percentage of weight loss of cayenne pepper to increase during storage.

Cayenne pepper in Polypropylene treatment of $0.5 \mathrm{~mm}+$ temperature of $5^{\circ} \mathrm{C}$ has a thicker plastic thickness and low temperature so that it can inhibit the respiration process so that the amount of oxygen entering the package is small and cayenne pepper looks fresh compared to the thickness of $0.3 \mathrm{~mm}$ packaging. Low permeability will reduce the rate of entry and exit of water vapor. According to Rochman (2007), polypropylene plastic provides protection against water loss in fruit, so that the packaged fruit still looks fresh because the polypropylene packaging has lower water vapor permeability properties so that the rate of air entering the material is increasingly inhibited. The packaging process will result in the modification of the atmosphere where the COconcentration 2 will be higher than 02. Modification of the atmosphere according to Kader and Moris (1997), will slow down the ripening process of the fruit, reduce the rate of ethylene production, slow down decay, and suppress various changes associated with ripening.

\section{Color}

Treatment Polypropylene $0.3 \mathrm{~mm}+$ temperature of $15^{\circ} \mathrm{C}$ has the lowest packing thickness at high temperatures will be experiencing respiratory process faster thereby increasing the degradation of the pigment. The young fruit is green because it contains chlorophyll. When the fruit gets old, chlorophyll turns into a natural pigment that is yellow, red, purple, or other colors according to the type of fruit (Sumoprastowo, 2000). 
Tri Luchi Proklamita, and Aloysius Ng. Lende

Table 6: Average Color of Cayenne Peppers Due to the Effect of Plastic Thickness and Temperature on Store Quality of Cayenne Peppers during Storage.

\begin{tabular}{|c|c|c|}
\hline \multirow{2}{*}{ Treatment } & \multicolumn{2}{|c|}{ Color } \\
\cline { 2 - 3 } & $8 \mathrm{DAS}$ & $16 \mathrm{DAS}$ \\
\hline Polypropylene $0,3 \mathrm{~mm}+$ suhu $5^{\circ} \mathrm{C}$ & 2,3 & $2,6 \mathrm{c}$ \\
\hline Polypropylene $0,3 \mathrm{~mm}+$ suhu $10^{\circ} \mathrm{C}$ & 2,6 & $3,2 \mathrm{e}$ \\
\hline Polypropylene $0,3 \mathrm{~mm}+$ suhu $15^{\circ} \mathrm{C}$ & 3,0 & $4,4 \mathrm{~g}$ \\
\hline Polypropylene $0,4 \mathrm{~mm}+$ suhu $5^{\circ} \mathrm{C}$ & 2,5 & $2,5 \mathrm{~cd}$ \\
\hline Polypropylene $0,4 \mathrm{~mm}+$ suhu $10^{\circ} \mathrm{C}$ & 2,7 & $2,7 \mathrm{~b}$ \\
\hline Polypropylene $0,4 \mathrm{~mm}+$ suhu $15^{\circ} \mathrm{C}$ & 2,8 & $3,6 \mathrm{f}$ \\
\hline Polypropylene $0,5 \mathrm{~mm}+$ suhu $5^{\circ} \mathrm{C}$ & 1,7 & $2,0 \mathrm{a}$ \\
\hline Polypropylene $0,5 \mathrm{~mm}+$ suhu $10^{\circ} \mathrm{C}$ & 2,4 & $2,8 \mathrm{~d}$ \\
\hline Polypropylene $0,5 \mathrm{~mm}+$ suhu $15^{\circ} \mathrm{C}$ & 2,9 & $3,8 \mathrm{f}$ \\
\hline HSD value $5 \%$ & $\mathrm{~ns}$ & 0,1 \\
\hline
\end{tabular}

Note: The numbers followed by the same letter in the same column are not significantly different in the HSD 5 test \%, ns, DAS: (Honestly Significance Diffirence, not significantly, Days After Saving).

Cayenne pepper in Polypropylene $0.5 \mathrm{~mm}+$ temperature of $5{ }^{\circ} \mathrm{C} \mathrm{mm}$ has a thicker plastic thickness and low temperature so that it can inhibit the respiration process and can reduce the rate of air circulation. This is supported by Pantastico (1993) which states that a low 02 concentration at a packaging thickness of $0.5 \mathrm{~mm}$ will inhibit the activation of ethylene, thereby reducing the effect of ethylene in accelerating ripening, decreasing respiration rate and decreasing substrate oxidation, delaying maturation and as a result, the age of the commodity becomes longer, chlorophyll breakdown is delayed and $\mathrm{C} 2 \mathrm{H} 4$ production is lower.

\section{CONCLUSION}

The combination treatment of packaging thickness and temperature had a very significant effect on the storage quality of cayenne pepper on weight loss, vitamin C, texture, moisture content, and color, but had no significant effect on the color of the 8th day of the watershed. The combination treatment of plastic packaging thickness of $0.5 \mathrm{~mm}$ and temperature of $5^{\circ} \mathrm{C}$ can give the best effect on texture, vitamin $\mathrm{C}$, moisture content, weight loss, and color, but at a thickness of $0.3 \mathrm{~mm}$ plastic and a temperature of $15^{\circ} \mathrm{C}$ does not give the best results on color day 8 .

\section{AUTHOR CONTRIBUTIONS}

TLP design and conduct research, data collection, data analysis, and also manuscript writing. ANL designs and conducts research, reviewing manuscripts, and submit manuscripts.

\section{SOURCES OF FUNDING}

This research received no specific grant from any funding agency in the public, commercial, or not-for-profit sectors.

\section{CONFLICT OF INTEREST}

The authors declared that the present study was performed in absence of any conflict of interest.

\section{ACKNOWLEDGMENT}

Thank you for the staff of the Agricultural Product Technology Laboratory, State Agriculture Polytechnic of Kupang, East Nusa Tenggara, Indonesia. The results of this study are dedicated to the development of science. 
The Effect of Polypropylene Thickness and Temperature on The Quality of Cayenne Pepper During Storage

\section{REFERENCES}

[1] Andarwulan, N., dan Koswara, S. 1992. Kimia Vitamin. Rajawali. Jakarta.

[2] Brown, W, E. 1992. Plastic in Food Packaging. Marcell Deker. USA.

[3] Buckle, K. A. 1987. Ilmu Pangan. Universitas Indonesia. Jakarta.

[4] Harper, J. L. 1986. Pangan, Gizi, dan Pertanian. Universitas Indonesia. Jakarta.

[5] Iflah, T. Sutrisno, dan T.C. Sunarti. 2012. Pengaruh kemasan starch-based plastics (Bioplastik) terhadap mutu tomat dan paprikaselama penyimpa nan dingin. Jurnal Tekn ologi in dust riPertanian. 22(3): 189-197.

[6] Kader, A. A., dan L.L. Moris. 1997. Relative Tolerance of Fruits and Vegetables to Elevated CO2 and Reduce 02 Levels. Michighan State University. Hort. Report.28:26. California 94022. Lang Meadsical Publicatins. Hal 21.

[7] Kismaryanti, A. 2007. Aplikasi Gel Lidah Buaya (Aloe vera) Sebagai Edible Coating pada Pengawetan Tomat (Lycopersicon esculentum). Fakultas Teknologi Pertanian. Institut Pertanian Bogor. Bogor.

[8] Langi, M. T. 2000. Ekstrak dan Karakteristik Oleoresin Cabai Rawit. Progam Pasca Sarjana UNSRAT. Manado.

[9] Lathifa, H. 2013. Pengaruh Jenis Pati sebagai Bahan Edible Coating dan Suhu Penyimpanan terhadap Kualitas Buah Tomat. Skripsi. Universitas Islam Negeri Maulana Malik Ibrahim. Malang.

[10] Meyer, I. H. 1973. Food Chemistry. Reinhold Publication Corporation. New York.

[11] Noor. Z. 1992. Senyawa Anti Gizi. PAU Pangan dan Gizi UGM. Yogyakarta.

[12] Pantastico. Er. B. 1975. Postharvest Physicology, Handling and Utilization of Tropical and Subtropical Fruits and Vegetables. Terjemahan Kamariyani. 1986. Gadjah Mada University Press: Yogyakarta.

[13] Prawirokusumo, S. 1994. Ilmu Gizi Kompratif. BPFE. Yogyakarta.

[14] Rochman, Agung. 2007. Kajian Teknik Pengemasan Buah Pepaya dan Semangka Terolah Minimal selama Penyimpanan Dingin. Skripsi. Fakultas Teknologi Pertanian. Institut Pertanian Bogor. Bogor.

[15] Santika, A. 2004. Agribisnis Cabai. Penebar Swadaya. Jakarta.

[16] Setiadi. 2001. Jenis dan Budidaya Cabai Rawit. Cetakan 9. Penebar Swadaya. Jakarta.

[17] Sumoprastowo. 2000. Memilih dan Menyimpan Sayur Mayur, Buah-Buahan dan Bahan Makanan. Bumi Aksara. Jakarta.

[18] Utama S M I, Perman M G D I, dan Gucker W J. 2002. Teknologi Pascapanen Hortikultura. Progam Studi Teknologi Pertanian Universitas Udayana. Denpasar.

[19] Wills Rhh, Lee TH, Graham D, Mcglasso, WB and Hall EG, 1981. Postharvest. Kensington Australia. New South Wales University Press Limited.

[20] Winarno, F G. 1993. Fisiologi Lepas Panen Produk Hortikultura. MBRIO. Bogor. 